\title{
Construction of Urban Tourism Image Based on Design Thought*
}

\author{
Yuting Li \\ School of Art and Design \\ Guangdong University of Finance \& Economics \\ Guangzhou, China
}

\author{
He Wang \\ Architectural Design \& Research Institute \\ Guangzhou University \\ Guangzhou, China
}

\begin{abstract}
For the construction of urban MICE (Meetings, Incentives, Conferencing/ Conventions, Exhibitions/ Exposition/ Event) tourism brand, the development of design thought, an academic concept, is a brand new way. In the past 30 years, the economic development in the country has cost huge social and natural environment in order to meet the minimum need of the people. As a large country in manufacturing, China is in the face of industrial transformation and upgrade as well as the technical wave of mobile information, social development factors such as upgrade of consumption need and quality have raised higher requirements over design research and design education. Based on the design thought, contemporary design research and design education have played an important role in driving and promoting the social development and design industry which cannot be ignored, and the driving effect of policies to fuse design industry and relevant industries need to be showed and carried out in a large scope. Based on analysis of status quo of creative design service in China, this article raises that to strengthen and advocate the design thought in the design industry policy is a strategy for creative design agency and state authorities to jointly create the urban MICE tourism brand images. Besides, it states that the design thought is development path to promote the design industry to upgrade in Chinese mainland.
\end{abstract}

Keywords-design thought; design management; design strength; MICE tourism; industrial integration

\section{INTRODUCTION}

Nowadays, China's economic has entered a new normal where factor drive is transformed to innovation drive, growth speed is transformed to development quality and benefits. Though China has become the largest manufacturing country throughout the world, yet the design and innovation capabilities of manufacturers are still incompetent. Creative design service activities are closely related to the first industry, the second industry and the third industry, of which, MICE has been confirmed as an important industry. Belonging to top end of industrial chains, the creative design service has

*This article is a research achievement of 2013 Guangdong Education Department Humanities \& Social Science Program “Applied Research of Integrative Thinking in Cultivating Talents of Creative Design Industry" (2013WYXM0047), 2015 Guangdong Philosophy \& Social Sciences CoConstruction Program "Abduction-based Design Thinking Methods and Its Applied Research" (GD15XYS02). 2015 Guangdong Education Department Educational Science Planning Program "Research on Product Development Mechanism of the Innovation Platform of Community Home-Based Care for the Aged in Guangdong" (2015GXJK042). features as rich knowledge, high added value, low energy consumption and low pollution, which plays a significant role in improving urban MICE tourism product and service quality, adding additional value, creating brands and promoting the competitiveness.

\section{PROBLEMS BACKGROUND}

In Mar 2014, China State Council released Several Opinions to Promote the Integrative Development of Cultural Creativity and Design Service and Relevant Industries, which was the first time to release a systematic file for the integrative development of cultural creativity and design service and relevant industries in the country. In Dec 2016, China State Council released State Strategic and Rising Industry Development Layout in the 13th Five-Year Plan, Tourism Development Layout in the 13th Five-Year Plan and so on, which aimed to further integrate cultural creativity, design service and MICE tourism, the creative design industry has gradually become an intellectual intensive labor promoting the efficient supply of quality product and service, and the creative economy, as a new development pattern, is rising. Currently the MICE tourism is closely depending on the technical industry, creative design and capital market for development, therefore, we need to promote the creative contents and modern technologies, strengthen the application of modern technologies in the creative service and drive the two-way integration of creativity and technologies so as to achieve the integration of innovative factors such as knowledge, creativity and design resources, design management and design enterprises, which are separated in space and organization, and further achieve the integrative innovation effect of creative design service and MICE tourism development. Innovative design is a creative integrative innovation and creation, it faces the era of knowledge network and takes industries as service object, having features of green and low carbon, intellectual, super-integrative and sharing, integrating technologies, cultural art and service mode innovation, and getting involved in diverse fields such as engineering design, industrial design and service design, and it is a key point to change technical achievements into productivities, which do good to and lead a new round of industrial revolution. Currently the design thought is a promoting factor for the practice, and the design thought is no long taken as a phenomenon in the design field, instead, it has been taken as an important practice method for the innovative 
activities of human being. Relying on the construction of infrastructure and policy support, the thinking thought can promote the social innovation and lead a new round of industrial revolution. In Guangzhou and Shenzhen, relying on the practice experience in Internet Plus enterprise, service enterprises and manufacturers, it is used for active attempt in the construction of urban brand development with the integration of MICE tourism and creative design.

Seen from the industrial upgrade, creative design is a top end hub in the coming industrial clusters. In addition to traditional design, according to the need of urban brand image construction in the era of information, the creative design may take digital media and communication technologies as tools and the design thought as bridge so as to improve the urban brand images and development competitiveness. The important point is, we should make use of the philosophy of design thought to promote urban brands, create urban brand images, improve urban value and make a logical use of urban resources.

\section{A GOOD WAY For DESIGN THOUGHT: NECESSARY WAY FOR INDUSTRIAL DEVELOPMENT}

\section{A. Transformation of Design Thought: from Trace to Lead}

Driven by the design activities by famous design enterprises, experts and scholars of the field at home and abroad have formed a consensus of re-understanding the design thought. Theories and research methods of design thought have extended to commercial and social fields from design, forming a hot academic problem and research field. The latest academic research orientation shows that a great number of internationally famous enterprises have greatly regarded the influence of design thought to enterprise innovation and their necessary connection, all of which strengthen and make use of intellectual resources in colleges to develop design management process, methods and concepts to fit the enterprise development of their own. Especially in the American Silicon Valley, a lot of technical innovation enterprises have established cooperation with colleges with acute insight so as to fully dig innovative factors in enterprises and make them be core competitiveness for success. Can the design thought resources in commercial innovation be used for the specific construction of urban MICE tourism brand image with new theories raised? This is the starting point and contents to be discussed in this article and the design thought is a major internal mechanism to promote the cooperative development of design industry and MICE tourism and start the construction of urban brand images at a high level.

\section{B. Ways for Urban MICE Tourism Innovative Design Development}

Stage I (2016-2025)

Relying on advantageous enterprises and regional industrial clusters, based on city, tourism and design (CTD) and guided by urban development and market demand, we should launch the urban planning innovation and tourism destination product innovation according to the actual situation and needs of urban development. Driven by key technology development, it needs to research and develop high quality design core and key technologies so as to create an urban brand images featuring high integration, high compatibility, high specialty and high stability. Driven by tourism investment funds, we should guide the social capital flow through market-oriented fund raising platforms, collect development funds, promote the development and construction of tourism infrastructure and tourist attractions, boost the structural upgrade of tourism, dig and cultivate quality tourism resources.

\section{Stage II (2026-2035)}

Create a batch of internationally famous urban innovate design and construction enterprises, rely on basic research and technical innovation, develop from initial meeting market demand to innovative design led market development and greatly improve the influence and reputation of our country among international cities.

During the collection and operation of tourism investment funds and resorts investment funds, all participants should fully understand state and local development strategies in tourism development, guided by clear industrial policies, well coordinate local cities and enterprises to cooperate, social funds to participate in and regulate the industrial investment funds, promote governmental preferential policies and policy support. Besides, it needs to establish and improve fund investment decision-making systems and flows so as to strictly control the risks in fund investment and operation.

\section{Stage III (2036-2050)}

Rely on the urban development law, information technology and global network, strengthen the urban destination and image design, build an innovation design system with brand image integration and urban supplies meeting the urban development in the country so as to achieve the ultimate goal of urban smart design.

\section{SUGGESTIONS FOR THE BASIS OF DESIGN THOUGHT}

\section{A. Cultivate Core Competitiveness of Cultural Creativity and Design Service-Design Thought}

To cultivate and develop design thought will greatly promote the upgrade of urban and local industrial structures, forming more powerful and persistent industrial competitiveness, which helpfully and efficiently improve the regional position and create a lot of new jobs. To build creative design environment and create its core competitiveness are important measures to achieve the smart development and regional prosperity of cities.

Seen from sustainable development, design thought is a significant way to protect ecological environment, build an environment friendly and resources-saving society. The environment and resources in the country are still tense, and there are no adequate land resources available, with the deteriorating air quality, environmental safety situation is more server than ever. The creative design industry has features and strengths of modern industry such as rich knowledge, high added value, low energy consumption and 
low pollution, which is an important engine for the industrial structure upgrade.

Design thought is an important part and a core content of cultural creative industry and a significant engine to improve urban cultural taste. In early years, it was wrongly thought that the functions of design thought were decoration and packaging, a branch of fine art. Actually the design can improve the living quality of the people, lead the fashion in daily life, cultivate esthetic sentiment, create comfortable life, and build a poetic habitat and elegant living environment so as to satisfy the people in spirit and culture.

\section{B. Strengthen the Propaganda of Design Thought Concept and Foster Creative Consumption Market Patterns}

According to the MICE business that are rapidly developing, explore a new way to reform and meet the development trend, such as destination management company (DMC). DMC is a state that is beyond traditional travel agencies, which aims to integrate resources needed by MICE, providing more creative and excellent destination service, including planning MICE activities, relevant sightseeing and providing professional arrangement in traditional agency business such as food \& beverage, traffic and amusement through rich destination knowledge. Actively introduce and promote the design thought concept to the public, strengthen the propaganda of creative media via media, improve the propaganda mechanism of creative design, support the promotion and making of propaganda supplies of park-based enterprises. Propagandize and recommend Chinese creative design brands through diverse channels and forms at high levels, popularize the design thought concept, integrate creativity to daily life, launch activities to promote and show creative design and exchanges. Governments shall transfer special funds to support the activities and provide creative design enterprisers with platforms of product and achievements exhibition. Diverse exchanges can be launched to improve the creative design concept, foster consumption groups and market and increase the reputation and influence.

\section{CONCLUSION}

Creative design is an important part and core content of cultural creative industry and a significant engine to improve the urban cultural taste. Design agencies should assist the urban decision makers to more deeply understand users' potential needs and chances, helping them clearly form a claim of urban development value of its own, establish design strategies applicable in different stages and form creative urban image experience on the basis of the recognition. With the design market more complicated at home, the information technology reforms have speeded up the renewal and changes of feeling experience of the people, driven by internal and external power for transformation and upgrade of creative design industry, the design service has to perfect its core competitiveness that is a necessary trend for the industrial development.

\section{REFERENCES}

[1] Ye Lang, Annual Development Report of Cultural Industry in China [M] Peking University Press, 2015.

[2] Lou Yongqi, On Initiative Design in the Era of Transformation [J]. Decoration, 2015.07.

[3] Roger Martin, The Design of Business: Why Design Thinking is the Next Competitive Advantage [M]. Mechanical Industry Press, 2014.

[4] Innovative Design Development Strategic Research Project Group, Comprehensive Report of Innovative Design Strategy [M]. Science and Technology of China Press, 2016. 